\title{
POTENTIAL OF ESSENTIAL OILS FOR THE CONTROL OF BROWN EYE SPOT IN COFFEE PLANTS
}

\section{Potencial de óleos essenciais no controle da cercosporiose-do-cafeeiro}

\author{
Ricardo Borges Pereira ${ }^{1}$, Gilvaine Ciavareli Lucas², \\ Fabiano José Perina ${ }^{2}$, Mário Lúcio Vilela de Resende² ${ }^{2}$ Eduardo Alves $^{2}$
}

\begin{abstract}
The objectives of this work were to assess the in vitro effect of essential oils extracted from cinnamon, citronella, lemon grass, India clove, tea tree, thyme, neem and eucalyptus on the conidia germination and on mycelial growth of Cercospora coffeicola, and their efficacy to control the brown eye spot in coffee seedlings (cultivars Catucaí 2SL, Catuaí IAC 62 and Mundo Novo 379/19) in a greenhouse, as well as their effects on the initial germination and infection events by scanning electron microscopy. All essential oils promoted the inhibition of conidia germination with increasing concentrations. India clove, cinnamon, neem, thyme and lemon grass oils inhibited the mycelial growth of $C$. coffeicola. The cinnamon and citronella oils were the most promising for brown eye spot control in all cultivars. In scanning electron microscopy, the cinnamon and citronella oils reduced germination and mycelial development of $C$. coffeicola in vivo, eight and 16 hours after inoculation, promoting, in some cases, the leakage of the cellular content. Essential oils of cinnamon and citronella reduced the incidence and severity of brown eye spot, in addition to presenting direct toxicity to the pathogen.
\end{abstract}

Index terms: Coffea arabica, Cercospora coffeicola, alternative control.

\section{RESUMO}

Este trabalho avaliou o efeito in vitro de óleos essenciais extraídos de canela, citronela, capim-limão, cravo-da-índia, árvorede-chá, tomilho, nim e eucalipto na germinação de conídios e no crescimento micelial de Cercospora coffeicola, a eficácia destes óleos no controle da cercosporiose-do-cafeeiro em mudas das cultivares Catucaí 2SL, Catuaí IAC 62 e Mundo Novo 379/19 em casa de vegetação; e seus efeitos sobre os eventos iniciais de germinação e infecção do patógeno in vivo por meio de microscopia eletrônica de varredura. Todos os óleos essenciais inibiram a germinação dos conídios com o aumento das concentrações. Os óleos de cravo-daíndia, canela, nim, tomilho e capim-limão inibiram o crescimento micelial de $C$. coffeicola. Os óleos de canela e citronela foram os mais promissores no controle da cercosporiose em todas as cultivares. Em microscopia eletrônica de varredura, os óleos de canela e citronela reduziram a germinação e o desenvolvimento micelial in vivo de $C$. coffeicola oito e 16 horas após a inoculação, promovendo, em alguns casos, o extravasamento do conteúdo celular. Óleos essenciais de canela e citronela reduziram a incidência e a severidade da cercosporiose, além de apresentar efeito tóxico direto ao patógeno.

Termos para indexação: Coffea arabica, Cercospora coffeicola, controle alternativo.

\section{(Received in July 6, 2010 and approved in September 14, 2010)}

\section{INTRODUCTION}

The brown eye spot, caused by Cercospora coffeicola Berk \& Cooke, is one of the most important disease of the coffee plant (Coffea arabica $\mathrm{L}$.), causing yield losses of up to $30 \%$. The pathogen infects the plantlets in the nursery and also those in production stage, affecting leaves and fruits (Zambolim et al., 2005). The disease usually causes intense plant defoliation, predisposing the fruits to infection by others pathogens. Affected fruits have their maturation process accelerated, which provokes their fall before the harvest and, consequently, depreciation of the drink quality (Pozza, 2008).
The brown eye spot is conventionally controlled using protective and systemic fungicides (Zambolim et al., 2005; Abrahão et al., 2009). However, the use of these products can eventually offer health and environmental risks and also can lead to the development of resistant strains of the pathogens (Santos et al., 2006). On the other hand, the use of essential oils extracted from medicinal plants makes up a promising strategy, since, besides presenting antimicrobial properties (Schwan-Estrada \& Stangarlin, 2003) and they were found to be promising for the alternative control of some plant diseases (Guiraldo et al., 2004). Fiori et al. (2000) reported the fungitoxic activity of essential oils extracted from lemongrass (Cymbopogon citratus (A.D.) Stapf and eucalyptus (Corimbia citriodora

${ }^{1}$ Empresa Brasileira de Pesquisa Agropecuária/Embrapa Hortaliças - Centro Nacional de Pesquisa de Hortaliças - BR 060 - Km 09 - Cx. P. 218 70359970 - Gama, DF - ricardobp@cnph embrapa br

${ }^{2}$ Federal University of Lavras/UFLA - Department of Plant Pathology/DFP - Lavras, MG 
Hook) on the germination and mycelial growth of Didymella bryoniae (Fuckel). Ranasingue et al. (2002) observed the fungitoxic activity of India clove (Syzygium aromaticum (Linne) Merril) and cinnamon (Cinnamomum zeylanicum Blume.) oils in vitro control of $C$. musae, Lasiodiplodia theobromae (Pat.) Griff \& Maubl. and Fusarium proliferatum (Matsuhima) Nirenberg.

Some researchers observed that, besides the in vitro activity, the essential oils present potential for the control of some diseases. Medice et al. (2007) and Pereira et al. (2008) observed that the thyme essential oil reduced the severity of both brown eye spot in the coffee plant and rust in soybean in the greenhouse and field, respectively. Carneiro (2003) related the efficiency of neem (Azadirachta indica A. Juss) oil to control of powdery mildew (Oidium lycopersici Cooke \& Massee) in tomato (Solanum lycopersicum L.), and Lima et al. (2008) reported the efficiency of citronella (Cymbopogon nardus (L.) Rendle) essential oil on ramulosis (Colletotrichum gossypii var. cephalosporioides) control in cotton (Gossypium hirsutum L.).

This work evaluated the in vitro effect of eight medicinal plant essential oils on the conidia germination and mycelial growth of $C$. coffeicola, their efficacy in the control of brown eye spot in three coffee plant cultivars, and their effects on the initial germination and infection events of the pathogen using scanning electron microscopy.

\section{MATERIAL AND METHODS}

The trials were conducted in the Federal University of Lavras (Lavras, State of Minas Gerais State), in the period from March to December of 2008.

For the obtaining of the C. coffeicola inoculum, naturally infected coffee plant leaves were collected in the field and submitted to a humid chamber for three days. Removal of the produced conidia took place next, using a soft bristle brush moistened in distilled water. The suspension obtained was filtered in gauze and concentration determined in a hemocytometer and adjusted to $1.5 \times 10^{4}$ conidia $\mathrm{mL}^{-1}$. This concentration was used in all the experiments.

The essential oils of all species used in the experiments were acquired from Professor Accorsi Medicinal Plants $^{\circledR}$ (Piracicaba, São Paulo State, Brazil, phone: (19) 33011502, e-mail: profaccorsi@ profaccorsi.com.br).

To evaluate the toxicity on the $C$. coffeicola germination, the essential oils extracted from tea tree (Melaleuca alternifolia Cheel), cinnamon (Cinnamomum zeylanicum Breym), lemongrass (Cymbopogon citratus
Staph), citronella, India clove (Sizygium aromaticum L.), eucalyptus (Corymbia citriodora Hook), neem and thyme (Thymus vulgaris L.) were tested at the concentrations of $0,250,500,1000,1500$ and $2000 \mu \mathrm{L} \mathrm{L}^{-1}$ in distilled and sterilized water. Powdered milk, $10 \mathrm{~g} \mathrm{~L}^{-1}$ in distilled and sterilized water, was added as a natural emulsifier at the concentrations of $2000 \mu \mathrm{L} \mathrm{L}^{-1}$, from which came the other dilutions. In order to isolate the effect of the powdered milk, a treatment only composed by this substance was added to the experiment at a concentration of $2000 \mu \mathrm{L} \mathrm{L}^{-1}$.

Petri dishes of $6 \mathrm{~cm}$ diameter were used with $2 \%$ $(\mathrm{w} / \mathrm{v})$ agar-water medium (AW). The treatments were added to the medium, after the fall of the temperature to $40^{\circ} \mathrm{C}$, before it was poured on the dishes, so that the final dilutions reached the pre-established ones. After the solidification of the medium, $500 \mu \mathrm{L}$ of the conidia suspension of the pathogen were deposited on its surface and spread with a Drigalsky spatula. Next, the dishes were incubated at $25^{\circ} \mathrm{C}$, with a 12 hour photoperiod, for 24 hours. The experiment was conducted in an entirely randomized design, with two dishes for each treatment, and each one divided into four quadrants, where 30 conidia per quadrant were appraised, in a total of eight repetitions. After incubation, the germination was paralyzed by the addition of four drops of lactoglycerol solution and the conidia germination percentage appraised under a light microscope.

To evaluate the toxicity of the essential oils on the mycelial growth of $C$. coffeicola, the same treatments evaluated in the germination test were used. However, only the concentration of $1000 \mu \mathrm{L} \mathrm{L}^{-1}$ was used. Petri dishes with $11 \mathrm{~cm}$ diameter were used with $2 \%(\mathrm{w} / \mathrm{w} / \mathrm{w})$ potato dextrose agar medium (PDA). This medium was prepared and poured in the dishes according to methodology described in the previous experiment. In the center of each dish, a $6 \mathrm{~mm}$-diameter disk of medium containing young (four days old) $C$. coffeicola mycelium was added. Afterwards, the fungal cultures were incubated at $25^{\circ} \mathrm{C}$ with a 12 hour photoperiod, remaining under those conditions until the end of the evaluations. The experiment was conducted in an entirely randomized design, with eight repetitions, each plot composed by one dish. Evaluations of the colony diameters were carried out every four days, until the mycelium of the control treatment occupied the whole surface of the medium. Soon afterwards, mycelial growth speed index (MGSI) calculations were made, by adaptation of the Maguire (1962) formula.

With the objective of evaluating the efficiency of the essential oils in the control of the brown eye spot, 
three coffee plant cultivars, susceptible to $C$. coffeicola were chosen: Mundo Novo 379/19, Catuaí IAC 62 and Catucaí 2SL. The seedlings of them were acquired at six months of age from the Experimental Station of EPAMIG South Minas Research Center (Lavras, Minas Gerais State, Brazil) - and transplanted to vases of seven liters containing a substrate composed of soil, bovine manure and sand, at a 2:1:1 proportion. The plants were maintained in a greenhouse during the whole experimental period, where they were periodically irrigated and fertilized according to the recommendations (Ribeiro et al., 1999).

At nine months of age, the coffee plants were sprayed until dripping with the essential oils of tea tree, cinnamon, lemongrass, citronella, India clove, eucalyptus, neem and thyme at the concentration of $1000 \mu \mathrm{L} \mathrm{L}^{-1}$, powdered milk $10 \mathrm{~g} \mathrm{~L}^{-1}$, acibenzolar-S-methyl (ASM) $\left(\right.$ Bion $\left.^{\circledR}\right) 200 \mathrm{mg} \mathrm{L}^{-1}$, this used as resistance induction standard, and distilled water (control), using manual sprayer. After 30 days, these treatments were repeated. Seven days after the first application, the plants were inoculated with $C$. coffeicola conidia suspension. Soon afterwards, the plants were maintained in humid chamber for 14 hours. The experiment was conducted in a randomized block design, with three repetitions, and the plot was composed by six plants. Five evaluations of the brown eye spot were made starting from the $21^{\text {st }}$ day after the inoculation at 14 day intervals, according to the diagrammatic scale of Kushalappa \& Chaves (1980). Soon afterwards, the areas under the incidence progress curve (AUIPC) and severity of brown eye spot (AUSPC) were calculated, according to Shaner \& Finney (1977).

To evaluate the initial $C$. coffeicola germination and infection events, nine months-coffee plant seedlings from Mundo Novo 379/19, Catuaí IAC 62 and Catucaí 2SL cultivars were used and cultivated following the previously described methodology. The coffee plants were sprayed until dripping with the two most promising essential oils obtained in the previous experiment, in this case, the essential oils of cinnamon and citronella at the concentration of $1000 \mu \mathrm{L} \mathrm{L}^{-1}$. A control sprayed only with distilled and sterilized water was added to the experiment. Two days later, eight leaves of the third pair from each treatment were collected, washed in distilled and sterilized water and placed in plastic trays, previously disinfested and prepared, according to Magnani et al. (2007). On the abaxial surface of each leaf, six circles of $1.0 \mathrm{~cm}$ in diameter were drawn with permanent marked pen. In the center of each circle, one drop of $25 \mu \mathrm{L}$ of the $C$. coffeicola conidia suspension was deposited. The trays with the leaves were covered with transparent plastic film and maintained in a growth chamber at $25^{\circ} \mathrm{C}$ and 12 hour photoperiod, until the end of the experiment. The sample collections for observation under a LEO EVO 40 Scanning Electron Microscope were done at four, eight, 16 and 48 hours after the inoculation, using circular cuts (five diameter mm) made with scalpel within each previously demarcated circle. The preparation and the observation of the samples were carried out according to Bossola \& Russell (1998).

The statistical analyses of the data were conducted using the Sisvar v. 4.5 statistical software. The qualitative means were grouping using the Scott-Knott test $(\mathrm{p} \leq 0.05)$ and regression graphs were generated for quantitative ones. The conidia germination percentage data were transformed to " $(\sqrt{+} 1)$.

\section{RESULTS AND DISCUSSION}

The germination of the conidia presented quadratic behavior as the essential oil concentrations increased (Figure 1). The cinnamon, citronella, lemongrass and thyme oils totally inhibited the germination of the conidia starting from $1000 \mu \mathrm{L} \mathrm{L}^{-1}$, while India clove and tea tree oils totally inhibited the conidia germination starting from 1500 and $2000 \mu \mathrm{L} \mathrm{L}^{-1}$, respectively. Even at the highest concentration used, the eucalyptus and neem oils did not totally inhibit the germination of the $C$. coffeicola conidia.

The essential oils of cinnamon and citronella totally inhibited the mycelial growth of $C$. coffeicola, however, without differing from neem oil, which presented a reduction of $95.13 \%$ in the mycelial growth speed index (MGSI) (Figure 2). Thyme and lemongrass essential oils reduced MGSI in $56.14 \%$ and $13.78 \%$, respectively, while the other oils did not differ from the control and the powdered milk.

In the same way Rozwalka et al. (2008) verified that the essential oil of lemongrass presented fungitoxic activity on the mycelial development of Glomerella cingulata (Stonemam) Spauld \& Schrenk and C. gloeosporioides. Souza et al. (2004) also verified that the essential oils of cinnamon $\left(200 \mu \mathrm{g} \mathrm{mL}^{-1}\right)$, India clove and thyme $\left(600 \mu \mathrm{g} \mathrm{mL}^{-1}\right)$ completely inhibited the in vitro mycelial development of Rhizopus sp., Eurotium repens De Bary and Aspergillus niger. According to Caccioni \& Guizzardi (1994), essential oils do possess great amounts of monoterpenes (d-limonene, cineole, b-myrcene, anethole, p-anisaldehyde, carvacrol, carvone, limonene, $\alpha$-felandreno, $\alpha$-pinene, etc.), which are responsible for the germination inhibition of several pathogens, due to their bactericidal and fungicidal properties. 

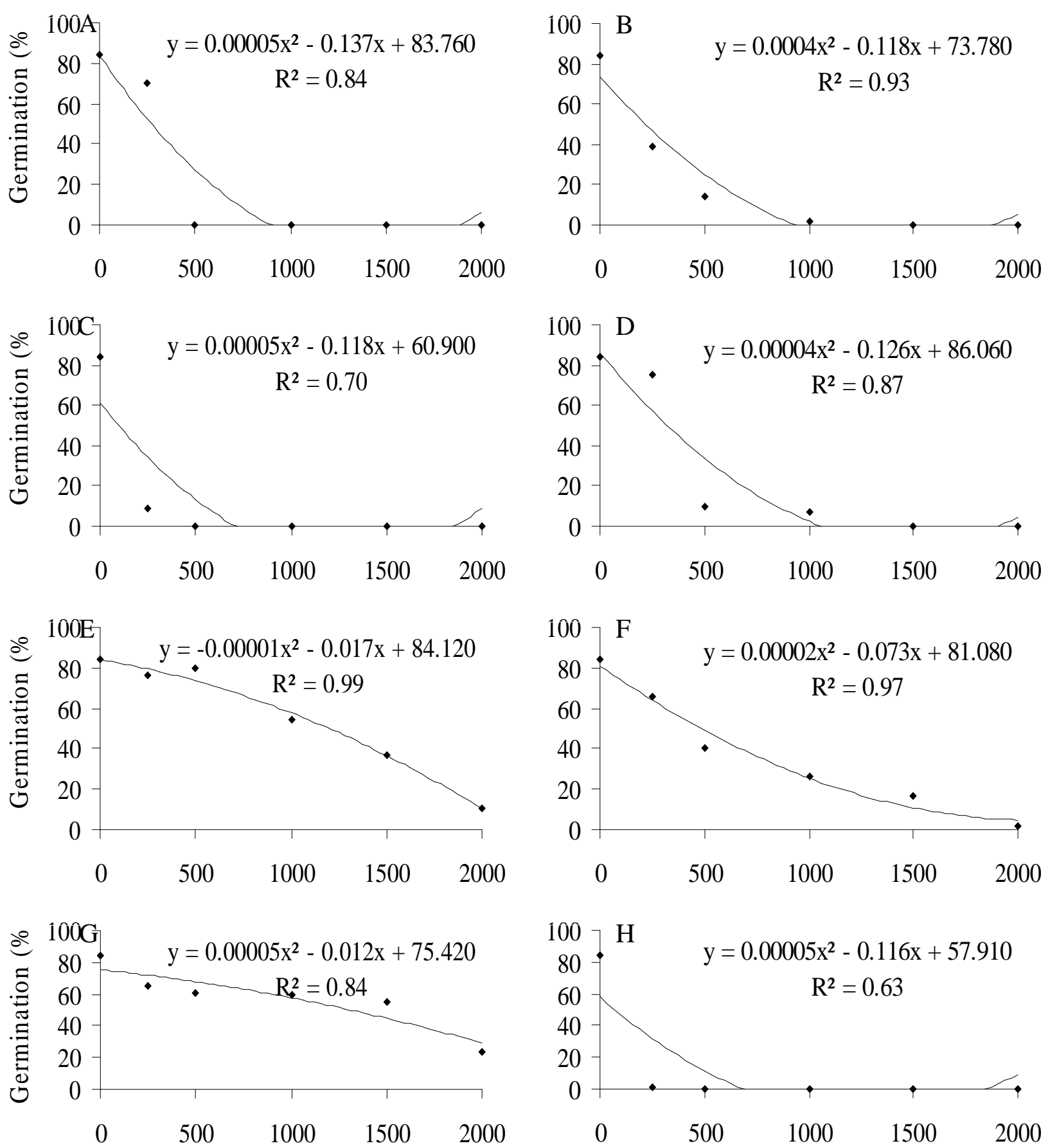

Concentration $\left(\mu \mathrm{L} \mathrm{L}^{-1}\right)$

Concentration ( $\mu \mathrm{L} \mathrm{L-1})$

Figure 1 - Percentage of Cercospora coffeicola conidia germination, submitted to different concentrations $(0,250,500$, 1500 and $2000 \mu \mathrm{L} \mathrm{L}^{-1}$ ) of essential oils extracted from cinnamon (A), citronela (B), lemongrass (C), India clove (D), eucalyptus $(\mathrm{E})$, tea tree $(\mathrm{F})$, neem $(\mathrm{G})$ and thyme $(\mathrm{H})$. Data transformed to " $(\sqrt{+} 1)$. 


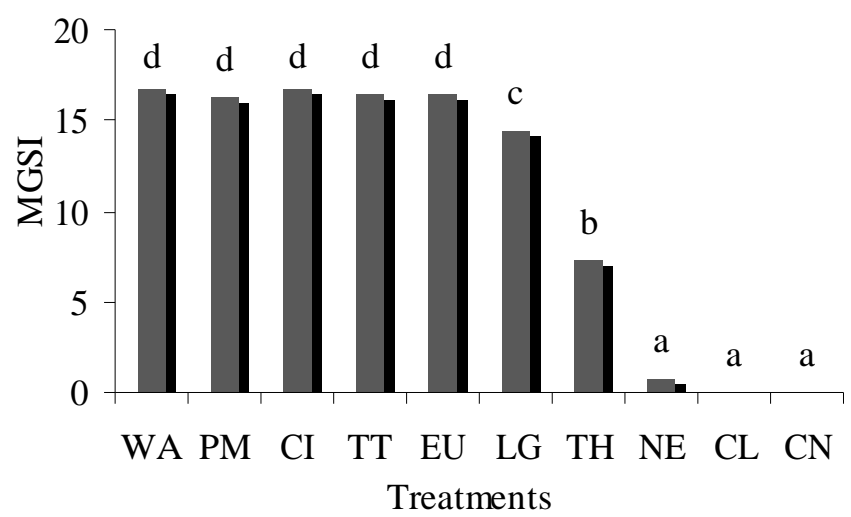

Figure 2 - Mycelial growth speed index (MGSI) of Cercospora coffeicola, submitted to essential oils extracted from India clove (CL), cinnamon (CN), neem (NE), thyme (TH), lemongrass (LG), eucalyptus (EU), tea tree (TT) and citronella (CI) at a concentration of $1000 \mu \mathrm{L} \mathrm{L}^{-1}$, powdered milk (PM) $10 \mathrm{~g} \mathrm{~L}^{-1}$ and distilled water (WA). Averages followed by same letter do not differ among themselves by the Scott-Knott test $(\mathrm{p} \leq 0.05)$.

The substances present in the essential oils, when in contact with the microorganisms, affect the integrity of the cell membranes, causing the spilling out of their contents (Piper et al., 2001). This fact has been observed by Medice et al. (2007) in soybean sprayed with essential oil of thyme and inoculated with P.pachyrhizi, and Pereira et al. (2008) in coffee plants treated with essential oil of thyme and inoculated with $C$. coffeicola and also by Cox et al. (2000) in Saccharomyces sp. exposed to the essential oil of tea tree.

In the experiment conducted in the greenhouse, no phytotoxicity symptom was observed due to the application of the essential oils. Significant interaction was not observed in the area under the incidence progress curve (AUIPC) of brown eye spot for the cultivars and products or substances. However, it was significant for the area under the severity progress curve (AUSPC). The cultivars Catuaí IAC 62 and Catucaí 2SL presented smaller AUIPC in relation to Mundo Novo 379/19 (Figure 3A). The acibenzolar-S-methyl standard treatment presented the highest reduction of AUIPC, $27.5 \%$, followed by citronella and cinnamon oils, with reductions of $12.0 \%$ and $10.0 \%$, respectively (Figure 3B). The other treatments did not differ among themselves and in relation to the controls.

Regarding the severity of the disease, it was verified that the AS treatment reduced AUSPC in Catucaí 2SL by $64.94 \%$ in relation to the control, followed by the citronella oil, with a reduction of $43.08 \%$ (Figure 3C). Eucalyptus, cinnamon and India clove oils reduced AUSPC by $21.08 \%, 21.05 \%$ and $10.80 \%$, respectively. In the Catuaí IAC 62 , AS treatment reduced AUSPC by $58.28 \%$, followed by the oil of cinnamon, with a reduction of $38.25 \%$
(Figure 3D). In the same cultivar, lemongrass, tea tree, thyme, eucalyptus, citronella and neem oils reduced AUSPC by $27.68 \%, 20.36 \%, 18.39 \%, 18.03 \%, 16.95 \%$ and $15.43 \%$, respectively. In the Mundo Novo 379/19, AS treatment reduced AUSPC by $55.91 \%$, followed by citronella and cinnamon oils, with reductions of $29.69 \%$ and $25.02 \%$, respectively (Figure $3 \mathrm{E}$ ). The other treatments did not differ in relation to the control.

Some authors confirmed the efficiency of acibenzolar-S-methyl and of some essential oils in the control of plant diseases. Pereira et al. (2008) obtained reductions of up to $35.0 \%$ and $16.1 \%$ in the area under the lesion number progress curve (AULNPC) in coffee plants sprayed with acibenzolar-S-methyl and essential oil of thyme, respectively. Possibly, the partial control of the disease obtained in this work by the application of the essential oils of cinnamon and citronella was due to the presence of compounds such as the cinnamaldehydes and eugenol and, geraniol and citronellal, respectively. According to Montes-Belmont \& Carvajal (1998) these are the components with higher antimicrobial properties present in these oils.

In the images generated by the scanning electron microscope, it could be observed to all cultivars that the germination of the $C$. coffeicola conidia began four hours after the inoculation, however, more significant differences were observed starting from eight hours after the inoculation (Figure 4). In the control leaves of the three cultivars, the conidia were in an advanced germination stage, with little mycelial development on their surface (Figure 4 C, F and I). However, in the observations made eight hours after inoculation in the leaves treated with the 
cinnamon and citronella oils, the conidia presented few and small germinal tubes, or even with non-germinated conidia. At 16 hours after the inoculation, the control leaves of the three cultivars presented well germinated conidia, with emission of a large number of germinal tubes and well developed mycelia. The same was not observed in the leaves sprayed with cinnamon and citronella oils to all the cultivars, in which the conidia were poorly germinating, with low germ tubes emission and poorly developed mycelia. In some conidia the spilling out of the cellular content can be observed, indicated by their plasmolization process.

Medice et al. (2007) treated soybean leaves with essential oil of thyme, $3000 \mu \mathrm{L} \mathrm{L}^{-1}$, and inoculated them with $P$. pachyrhyzi urediniospores seven days later. By means scanning electron microscopy observations, the authors verified a reduction in the size of the uredias and on the number of urediniospores, a part of which became plasmolized. Pereira et al. (2008) also verified such effect in

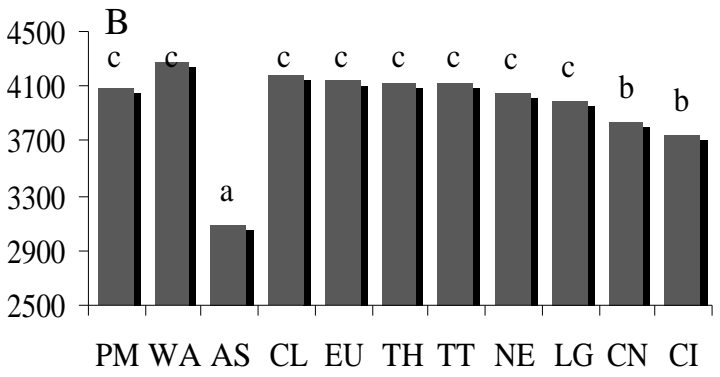

Treatments

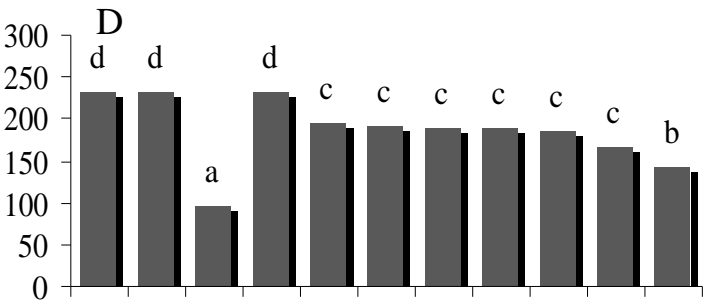

PM WA AS CL NE CI EU TH TT LG CN

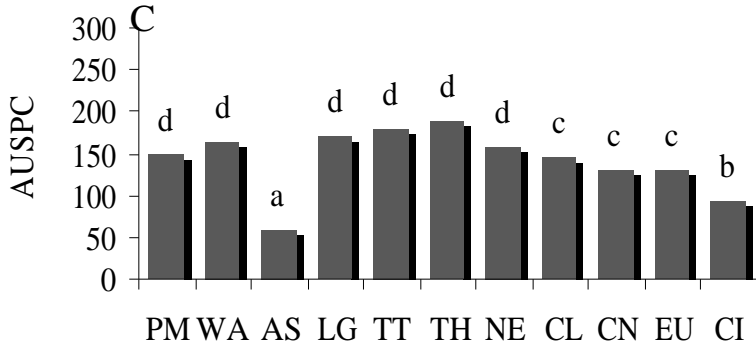

Treatments

Treatments

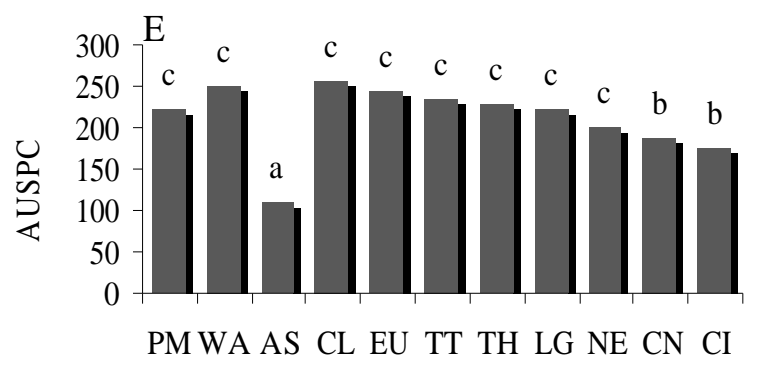

Treatments

Figure 3 - Areas under the incidence progress curve (AUPIC) (A and B) and severity of brown eye spot (AUSPC) (C, D and E) in the coffee plant cultivars Catucaí 2SL (C), Catuaí IAC 62 (D) and Mundo Novo 379/19 (E), treated with essential oils of citronella (CI), cinnamon (CN), lemongrass (LG), neem (NE), tea tree (TT), thyme (TH), eucalyptus (EU) and India clove (CL) at a concentration of $1000 \mu \mathrm{L} \mathrm{L}^{-1}$, acibenzolar-S-methyl (AS) $200 \mathrm{mg} \mathrm{L}^{1}$, powdered milk (PM) $10 \mathrm{~g} \mathrm{~L}^{-1}$ and distilled water (WA). Averages followed by same letter do not differ among themselves by the Scott-Knott test $(\mathrm{p} \leq 0.05)$. 

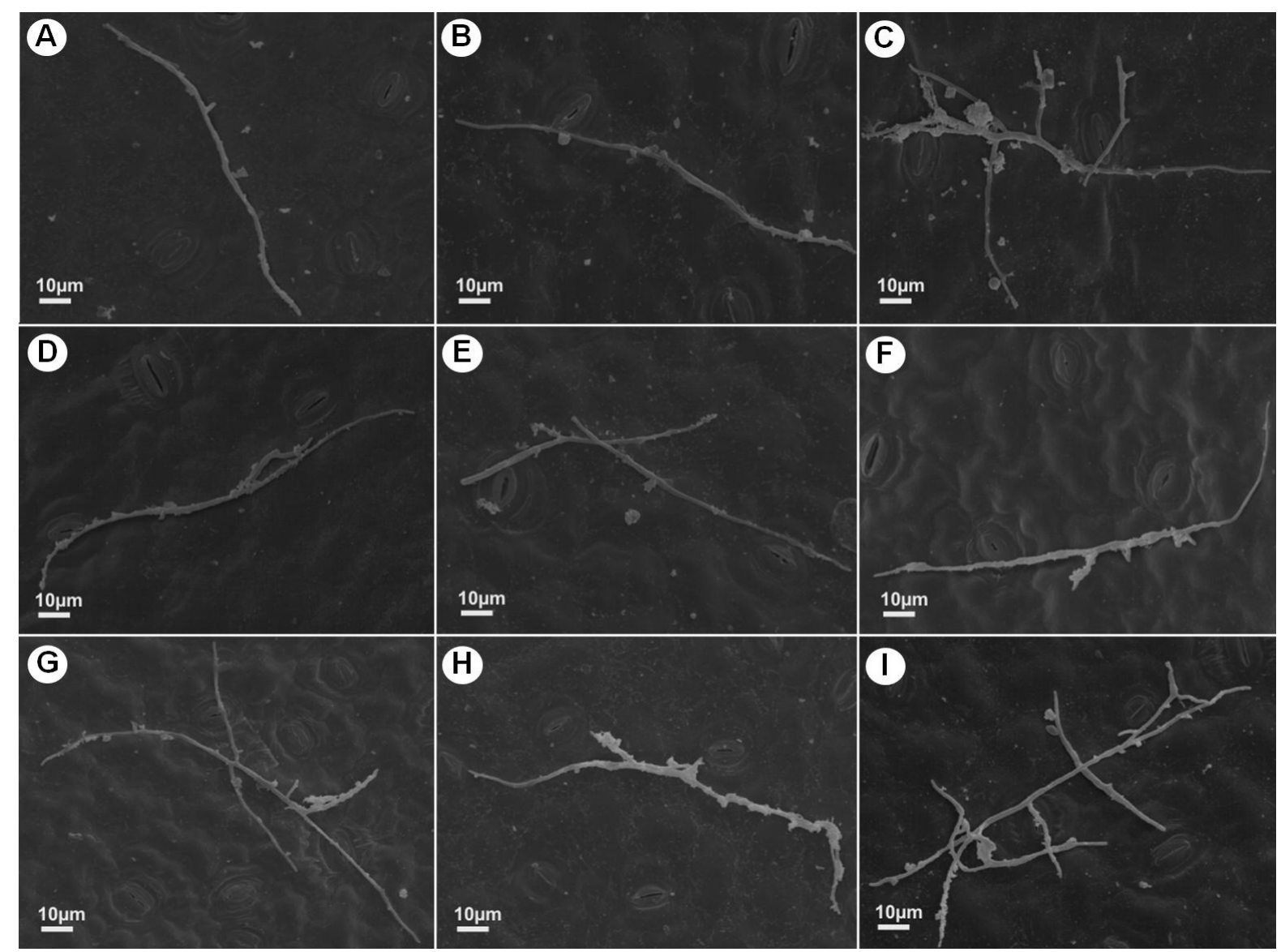

Figure 4 - Scanning electron micrographs of coffee leaves from coffee plant cultivars Mundo Novo 379/19 (A, B and C), Catuaí IAC 62 (D, E and F) and Catucaí 2SL (G, H and I) eight hours after inoculation with Cercospora coffeicola. Plants sprayed with essential oils of cinnamon $1000 \mu \mathrm{L} \mathrm{L}^{-1}(\mathrm{~A}, \mathrm{D}$ and $\mathrm{G})$ and citronella $1000 \mu \mathrm{L} \mathrm{L}^{-1}(\mathrm{~B}, \mathrm{E}$ and $\mathrm{H})$ presenting conidia at the initial germination stage and, distilled and sterilized water $(\mathrm{C}, \mathrm{F}$ and $\mathrm{I})$ presenting conidia at an advanced germination stage.

coffee plants sprayed with the thyme oil, $500 \mu \mathrm{L} \mathrm{L}^{-1}$, and inoculated with C. coffeicola. According to Amaral \& Bara (2005), essential oils possibly act in the cell wall of the fungi, causing the leakage of the cellular content. Such effect was also observed later by Rasooli et al. (2006), using transmission electron microscopy, where the essential oils of Thymus eriocalyx (Ronniger) Jalas and T. x-porlock promoted severe damage to the walls, membranes and cellular organelles of A. niger spores. According to the authors, mycelia exposure to the essential oils of $T$. eriocalyx and T. x-porlock induced morphological alterations in the hyphae, rupture of the plasma membrane and mitochondrial destruction.

It can be suggested that the control of brown eye spot in coffee plant cultivars was mainly due to the direct effect of the essential oils on the pathogen. However, complementally studies should be conducted. In the specific case of the coffee plant, it was verified that the essential oils of cinnamon and citronella were the most promising for control of brown eye spot. Therefore, they can be used in the control of the brown eye spot in seedlings and in fields under organic coffee production, in which the use of pesticides is not undertaken, combined with other strategies to reduce the use of chemical products, which, over time, can cause irreversible damages to human health and the environment.

\section{CONCLUSIONS}

The essential oils of cinnamon, citronella, lemongrass, India clove, tea tree, thyme, eucalyptus and 
neem reduced the Cercospora coffeicola conidia germination; the oils of India clove, cinnamon, neem, thyme and lemongrass inhibited the mycelial growth of C. coffeicola.

The essential oils promoted partial control of the brown eye spot in coffee plant in greenhouse. The oils of cinnamon and citronella were the most promising for the control of the disease in Catucaí 2SL, Catuaí IAC 62 and Mundo Novo 379/19 coffee plant cultivars.

The oils of cinnamon and citronella reduced the germination and the mycelial development of $C$. coffeicola, promoting, in some cases, the spilling out of the cellular content.

\section{ACKNOWLEDGMENTS}

To the Conselho Nacional de Desenvolvimento Científico e Tecnológico (CNPq) for the doctoral scholarship granted to the first author and to the Fundação de Amparo à Pesquisa do Estado de Minas Gerais (FAPEMIG) for financial support given to the Laboratório de Microscopia Eletrônica e Análise Ultraestrutural of the Universidade Federal de Lavras and to this study.

\section{REFERENCES}

ABRAHÃO, A.A.; PEREIRA, R.G.F.A.; BORÉM, F.M.; REZENDE, J.C. de; BARBOSA, J.C. Influência de safras agrícolas e tratamentos fungicidas no café cereja descascado e bóia. Ciência e Agrotecnologia (online), Lavras, v.33, n. Edição Especial, p.1919-1925, 2009.

AMARAL, M.F.Z.J.; BARA, M.T.F. Avaliação da atividade antifúngica de extratos de plantas sobre o crescimento de fitopatógenos. Revista Eletrônica de Farmácia, São Paulo, v.2, n.2, p.5-8, jun./dez. 2005.

BOSSOLA, J.J.; RUSSELL, L.D. Electron microscopy. Boston: Jones and Bartlett, 1998. 670p.

CACCIONI, D.R.L.; GUIZZARDI, M. Inhibition of germination and growth of fruit and vegetable postharvest pathogenic fungi by essential oil components. Journal of Essential Oil Reserch, Camberra, v.6, n.2, p.173-179, Mar./Apr. 1994.

CARNEIRO, S.M.T.P.G. Efeito de extratos de folhas e do óleo de nim sobre o oídio do tomateiro. Summa

Phytopathologica, Botucatu, v.29, n.3, p.262-265, jul./set. 2003.
COX, S.D.; MANN, C.M.; MARKHAM, J.L.; BELL, H.C.; GUSTAFSON, J.E.; WARMINGTON, J.R.; WYLLIE, S.G. The mode of antimicrobial action of the essential oil of Melaleuca alternifolia: tea tree oil. Journal Applied Microbiology, Oxford, v.88, n.1, p.170175, Jan. 2000.

FIORI, A.C.G.; SCHWAN-ESTRADA, K.R.F.; STANGARLIN, J.R.; VIDA, J.B.; SCAPIM, C.A.; CRUZ, M.E.S.; PASCHOLATI, S.F. Antifungal activity of leaf extracts and essential oils of some medicinal plants against Didymella bryoniae. Journal Phytopathology, Berlin, v.148, n.7/8, p.483-487, Aug. 2000.

GUIRALDO, N.; AMBROSANO, E.J.; MENDES, P.C.D.; ROSSI, F.; AVÉRALO, R.A. Medidas de controle de doenças em sistema agroecológicos. Summa Phytopathologica, Botucatu, v.30, n.1, p.153-156, jan./ mar. 2004

KUSHALAPPA, A.C.; CHAVES, G.M. An analysis of the development of coffee rust in the field.

Fitopatologia Brasileira, Brasília, v.6, n.1, p.95-113, fev. 1980.

LIMA, W.G.; SANTOS, R.C.; CÂMARA, C.A.G.; CÂMARA, M.P.S.; MELO FILHO, P.A. Citronella oil inhibits cotton ramulosis in controlled conditions. Pest Technology, v.2, n.1, p.24-27, Apr. 2008.

MAGNANI, E.B.Z.; ALVES, E.; ARAÚJO, D.V. Eventos dos processos de pré-penetração, penetração e colonização de Phakopsora pachyrhizi em folíolos de soja. Fitopatologia Brasileira, Brasília, v.32, n.2, p.156160, mar./abr. 2007.

MAGUIRE, J.D. Speed of germination-aid in selection and evaluation for seedling emergence and vigor. Crop Science, Madison, v.2, n.2, p.176-177, Jan. 1962.

MEDICE, R.; ALVES, E.; ASSIS, R.T.; LOPES, E.A.G.L. Óleos essenciais no controle da ferrugem asiática da soja Phakopsora pachyrhizi Syd. \& P. Syd. Ciência e Agrotecnologia, Lavras, v.31, n.1, p.83-90, jan./fev. 2007.

MONTES-BELMONT, R.; CARVAJAL, M. Control of Aspergillus flavus in maize with plant essential oils and their components. Journal of Food Protection, Ames, v.61, n.5, p.616-619, maio 1998. 
PEREIRA, R.B.; ALVES, E.; RIBEIRO JÚNIOR, P.M.; RESENDE, M.L.V. de; LUCAS, G.C.; FERREIRA, J.B. Extrato de casca de café, óleo essencial de tomilho e acibenzolar-S-metil no manejo da cercosporiose-docafeeiro. Pesquisa Agropecuária Brasileira, Brasília, v.43, n.10, p.1287-1296, out. 2008.

PIPER, P.; CALDERON, C.O.; HATZIXANTHIS, K.; MOLLAPOUR, M. Weak acid adaptation: the stress response that confers resistance to organic acid food preservatives. Microbiology, Washington, v.147, n.10, p.2635-2642, Oct. 2001.

POZZA, E.A. A Importância das doenças foliares do cafeeiro. In: NÚCLEO DE ESTUDOS EM FITOPATOLOGIA. Manejo fitossanitário da cultura do cafeeiro. Brasília: Sociedade Brasileira de Fitopatologia, 2008. p.81-94.

RANASINGHE, L.; JAYAWARDENA, B.; ABEYWICKRAMA, K. Fungicidal activity of essential oils of Cinnamomum zeylanicum (L.) and Syzygium aromaticum (L.) Merr et L.M. Perry against crown rot and anthracnose pathogens isolated from banana. Letters in Applied Microbiology, Cardiff, v.35, n.3, p.208211, Mar. 2002.

RASOOLI, I.; REZAEI, M.B.; ALLAMEH, A. Growth inhibition and morphological alterations of Aspergillus niger by essential oils from Thymus eriocalyx and Thymus x-porlock. Food Control, Reading, v.17, n.5, p.359-364, 2006.

RIBEIRO, A.C.; GUIMARÃES, P.T.G.; ALVAREZ, V.V.H. Recomendações para o uso de corretivos e fertilizantes em Minas Gerais: $5^{\text {a }}$ aproximação. Viçosa, MG: CFSEMG, 1999. 359p.
ROZWALKA, L.C.; LIMA, M.L.R.Z.C. da; MIO, L.L.M. de; NAKASHIMA, T. Extratos, decoctos e óleos essenciais de plantas medicinais e aromáticas na inibição de Glomerella cingulata e Colletotrichum gloeosporioides de frutos de goiaba. Ciência Rural, Santa Maria, v.38, n.2, p.301-307, mar./abr. 2008.

SANTOS, G.R.; CAFÉ-FILHO, A.C.; REIS, A. Resistência de Didymella bryoniae a fungicidas no Brasil.

Fitopatologia Brasileira, Brasília, v.31, n.5, p.476-482, set./out. 2006.

SCHWAN-ESTRADA, K.R.F.; STANGARLIN, J.R.; CRUZ, M.E.S. Uso de plantas medicinais no controle de doenças de plantas. Fitopatologia Brasileira, Brasília, v.28, p.554-556, 2003. Suplemento.

SHANER, G.; FINNEY, R.F. The effect of nitrogen fertilization on the expression of slow-mildewing resistance in knox wheat. Phytopathology, Sant Paul, v.67, n.8, p.1051-1056, Aug. 1977.

SOUZA, S.M.C. de; PEREIRA, M.C.; ANGÉLICO, C.L.; PIMENTA, C.J. Avaliação de óleos essenciais de condimentos sobre o desenvolvimento micelial de fungos associados a produtos de panificação. Ciência e Agrotecnologia, Lavras, v.28, n.3, p.685-690, maio/jun. 2004.

ZAMBOLIM, L.; VALE, F.X.R.; ZAMBOLIM, E.M. Doenças do cafeeiro (C. arabica e $C$. canephora). In: KIMATI, H.; AMORIM, L.; REZENDE, J.A.M.; BERGAMIN FILHO, A.; CAMARGO, L.E.A. (Ed.). Manual de fitopatologia: doenças das plantas cultivadas. 4.ed. São Paulo: Agronômica Ceres, 2005. v.2, p.165-180. 